\title{
PENGARUH KEPEMIMPINAN DAN DISIPLIN TERHADAP MOTIVASI \\ KERJA SERTA DAMPAKNYA PADA KINERJA PEGAWAI RUMAH SAKIT UMUM BERSAUDARA KABUPATEN BUNGO
}

\author{
M. Alhudhori, Wahyu Aldino \\ Dosen Fakultas Ekonomi Universitas Batanghari
}

\begin{abstract}
Leadership is one of the issues in the management is still quite interesting to be discussed today. The role of leadership is very strategically important for the achievement of the mission, vision and goals of an organization. One such way to impose discipline and provide motivation to work that can be perceived by employees. The purpose of this study was to examine the influence of leadership, discipline, motivation and performance. The influence of leadership, discipline, motivation and performance of employees tested either directly or indirectly. To examine issues directly above the survey conducted by distributing questionnaires to employees in the General Hospital of the Brothers of Bungo. Data was analyzed by path analysis. The results of this study indicate that the leadership, discipline and work motivation influence simultaneously and partially on performance. Where is the leadership, discipline, motivation and performance of employees at the General Hospital Brothers, where are the good category, Discipline are in both categories, motivation and performance of employees are in both categories. The analysis tool in this research using descriptive method verification. Where the use of a range of scales, while in the verification using path analysis or path analysis.
\end{abstract}

Key words : Leadership, Discipline, Motivation and Employee Performance

\section{PENDAHULUAN}

Dalam perkembangan zaman modern saat ini, berbagai macam aspek keunggulan dibutuhkan oleh setiap organisasi dalam rangka mencapai tujuannya. Sebuah organisasi atau perusahaan sangat memerlukan adanya suatu potensi dan kekuatan internal yang kokoh dalam rangka menghadapi semua tantangan, hambatan serta perubahan yang ada. Hal ini dikarenakan organisasi yang maju dan berkembang setiap saat mampu mengatasi masalah dengan solusi yang tepat sesuai situasi dan kondisi yang ada. Faktor utama yang dibutuhkan dalam rangka mewujudkan harapan organisasi tersebut adalah faktor sumber daya manusia.

Suatu organisasi membutuhkan pemimpin yang efektif, yang mempunyai kemampuan mempengaruhi perilaku anggotanya atau anak buahnya. (Alimuddin, 2002). Jadi, seorang pemimpin atau kepala suatu organisasi akan diakui sebagai seorang pemimpin apabila ia dapat member pengaruh dan mampu mengarahkan bawahannya ke arah tujuan organisasi.

Kepemimpinan merupakan salah satu isu dalam manajemen yang masih cukup menarik untuk diperbincangkan hingga saat ini. Peran kepemimpinan yang sangat strategis dan penting bagi pencapaian misi, visi dan tujuan suatu organisasi, merupakan salah satu motif yang mendorong manusia untuk selalu menyelidiki seluk-beluk yang terkait dengan kepemimpinan.

Kualitas dari pemimpin seringkali dianggap sebagai faktor terpenting dalam keberhasilan atau kegagalan organisasi (Bass, 1990, dalam Menon, 2002) demikian juga keberhasilan atau kegagalan suatu organisasi baik yang berorientasi bisnis maupun publik, biasanya dipersepsikan sebagai keberhasilan atau 
kegagalan pemimpin. Begitu pentingnya peran pemimpin sehingga isu mengenai pemimpin menjadi fokus yang menarik perhatian para peneliti bidang perilaku keorganisasian. Pemimpin memegang peran kunci dalam memformulasikan dan mengimplementasikan strategi organisasi. (Su’ud, 2000).

Kepemimpinan adalah suatu cara yang digunakan oleh seorang pemimpin dalam mempengaruhi perilaku orang lain. Gaya kepemimpinan merupakan norma perilaku yang dipergunakan oleh seseorang pada saat orang tersebut mencoba mempengaruhi perilaku orang lain. Masing-masing gaya tersebut memiliki keunggulan dan kelemahan. Seorang pemimpin akan menggunakan gaya kepemimpinan sesuai kemampuan dan kepribadiannya (Sukarno Marzuki, 2002).

Selain itu disiplin sangat penting untuk pertumbuhan organisasi, digunakan terutama untuk memotivasi pegawai agar dapat mendisiplinkan diri dalam melaksanakan pekerjaan baik secara perorangan maupun kelompok. Disamping itu, disiplin bermanfaat untuk mendidik pegawai untuk mematuhi dan menyenangi peraturan, prosedur, maupun kebijakan yang ada, sehingga dapat menghasilkan kinerja yang baik.

Terkadang tidak pahamnya pegawai tentang peraturan, prosedur, dan akan kebijakan yang ada merupakan penyebab terbanyak indisipliner. Salah satu upaya untuk mengatasi hal tersebut pihak pimpinan sebaiknya memberikan program orientasi kepada tenaga kerja. Disiplin yang baik mencerminkan besarnya rasa tanggung jawab seseorang terhadap tugas-tugas yang diberikan kepadanya. Hal ini mendorong gairah kerja, semangat kerja dan mendukung terwujudnya tujuan organisasi. Disiplin harus ditegakkan dalam suatu organisasi, karena tanpa dukungan disiplin kerja yang baik, maka sulit bagi perusahaan atau orgnisasi untuk mencapai tujuannya.

Dari aspek motivasi, Hasibuan $(2001,97)$ menyebutkan bahwa ada beberapa inidikasi yang memperlihatkan seorang karyawan termotivasi atau tidak termotivasi dalam bekerja, salah satu diantaranya adalah datang terlambat, tapi pulang lebih awal atau tidak masuk kerja tanpa ada alasan yang jelas. Jika dikaitkan antara aspek kepemimpinan dengan motivasi, maka dapat disimpulkan dengan terlihat adanya indikasi bahwa ada suatu kecenderungan pimpinan selalu pilih kasih dalam membebankan tugas kepada bawahannya.

Disamping itu indikasi lain yang ditemukan adalah adanya keluhan dari beberapa pegawai yang merasa kurang mendapatkan perhatian, dan belum memperoleh peran yang sesuai dengan pendidikannya, pengalaman kerjanya, maupun dari segi jabatannya, seperti pegawai tersebut merasa pimpinan memberikan perintah disaat pegawai tersebut sedang ada kerjaan namun rekan kerjanya sedang tidak ada tugas, dan juga pemberian jabatan juga tidak sesuai dengan latar belakang pendidikan juga gaji yang tidak sesuai.

Namun, pada sisi lainnya justru ada pegawai yang lebih rendah pendidikannya dan masa kerjanya mendapatkan peran yang lebih baik. Hal lain yang juga ditemukan adalah adanya indikasi bahwa meskipun pembagian tugas (job description) telah dilaksanakan, namun masih ada pegawai yang merasa belum diberi tugas, sehingga yang bersangkutan akan melaksanakan tugas jika diperintah oleh atasannya. Dan kalaupun mereka tahu tugas apa yang seharusnya mereka kerjakan, namun mereka merasa takut untuk mengerjakan pekerjaan tersebut karena takut disalahkan oleh atasan, sehingga mereka lebih banyak bersikap menunggu perintah atasan baru kemudian mereka akan mengerjakannya.

Oleh karena itu, tentu sangat diharapkan disiplin dari pegawai rumah sakit umum bersaudara tidak hanya batas kepercayaan yang diberikan oleh instansi dan 
pemimpin, tentu saja kesadaran dari masing-masing pegawai tersebut. Hal ini dimaksudkan agar dapat menunjukkan bahwa motivasi dari pemimpin dapat meningkatkan disiplin pegawai sehingga memperoleh kinerja yang bagi pegawai.

Penelitian ini bertujuan untuk mengetahui pengaruh kepemimpinan dan disiplin terhadap motivasi kerja serta dampaknya pada kinerja pegawai Rumah Sakit Umum Bersaudara Kabupaten Bungo.

\section{METODE PENELITIAN}

Dalam penelitian ini yang menjadi objek adalah pegawai Rumah Sakit Umum Bersaudara Kabupaten Bungo yang berjumlah 54 orang. Penelitian ini lebih diarahkan pada proses analisis hubungan antara kepemimpinan dan Disiplin terhadap motivasi kerja serta dampaknya pada kinerja pegawai Rumah Sakit Umum Bersaudara Kabupaten Bungo. Dalam penelitian ini variabel bebasnya adalah adalah Kepemimpinan $\left(\mathrm{X}_{1}\right)$ dan Disiplin $\left(\mathrm{X}_{2}\right)$, sedangkan variabel terikatnya adalah Motivasi kerja (Y) dan Kinerja pegawai (Z) Rumah Sakit Umum Bersaudara Kabupaten Bungo.

Uji validitas dalam penelitian ini dengan menggunakan criteria yang diambil dari alat ukur itu sendiri, yaitu dengan cara mengkorelasikan antara skor item dengan skor total ( keseluruhan item ), yang disebut validitas item yang digunakan dalam uji validitas tersebut adalah teknik keofisien korelasi dari Pearson (Metode Least Square). Adapun rumusan korelasi product moment adalah sebagai berikut :

$$
r x y=\frac{N\left(\sum X Y\right)-\left(\sum X \sum Y\right)}{\left.\sqrt{\left[N \sum X^{2}-\left(\sum X\right)^{2}\right] N \sum Y^{2}-\left(\sum Y\right)^{2}}\right]}
$$

Keterangan :

$r \mathrm{xy}=$ Koefisien Korelasi Product Moment

$\Sigma \mathrm{x} \quad=$ Jumlah Skor Item

$\Sigma \mathrm{x} \quad=$ Jumlah Skor Total

$\Sigma y \quad=$ Jumlah Skor Total

$\Sigma$ zy $=$ Jumlah Perkalian Antara Skor Item dan Skor Total

$\mathrm{N} \quad=$ Banyaknya Subyek

Sedangkan, Untuk menjawab tujuan pertama dan hipotesis pertama digunakan analisis deskriptif dengan alat analisis rentang skala. Analisis deskriptif mempunyai fungsi untuk memberikan gambaran umum tentang data yang telah diperoleh.

Kecendrungan dan variasi variabel motivasi kerja dan kinerja pada pegawai Rumah Sakit Bersaudara Kabupaten Bungo serta variabel kepemimpinan dan disiplin dapat ditentukan berdasarkan distribusi frekuensi untuk mengetahui apakah skor variabel yang diteliti terdapat pada kategori rentang skala, sangat buruk, buruk, sedang, baik dan sangat baik.

Untuk mengetahui kriteria tersebut, maka terlebih dahulu dibuat klasifikasi yang mengacu pada ketentuan rentang skor dan rentang skala dengan menggunakan rumus sebagai berikut :

1. Penentuan Rentang Skala

$$
\begin{aligned}
& \mathrm{RS}=\frac{n(m-1)}{M} \\
& \text { Keterangan : } \\
& \mathrm{RS}=\text { Rentang Skala } \\
& \mathrm{n} \quad=\text { Jumlah Sampel }
\end{aligned}
$$


$\mathrm{M}=$ Jumlah Alternatif Jawaban

Sehingga perhitungan skala sebagai berikut :

$\mathrm{RS}=\frac{54(5-1)}{5}$

$=43,2$

2. Penentuan Rentang Skala per item

- Rentang skor terendah $=\mathrm{n} \times$ skor terendah

$$
\begin{aligned}
& =54 \times 1 \\
& =54
\end{aligned}
$$

- Rentang skor tertinggi $=\mathrm{n} \times$ skor tertinggi

$$
\begin{aligned}
& =54 \times 5 \\
& =270
\end{aligned}
$$

Path Analysis ini mengikuti pola structural atau model structural dengan variabel penelitian Kepemimpinan (X1) dan Disiplin (X2) sebagai variabel indenpenden, Motivasi Kerja (Y) sebagai variabel antara (intervening) dan Kinerja (Z) sebagai variabel dependen. Sedangkan variabel lain yang tidak ukur atau diteliti dan berpengaruh terhadap Motivasi Kerja dan Kinerja pegawai disebut sebagai variabel epsilon $(\varepsilon)$.

Hubungan structural untuk diagram jalur diatas dinyatakan dengan persamaan sebagai berikut :

$\mathrm{Y}=\mathrm{PYX} 1 \mathrm{X} 1+\mathrm{PYX} 2 \mathrm{X} 2+\varepsilon$

Sedangkan hubungan structural antara variabel Kepemimpinan (X1) dan Disiplin (X2) terhadap Motivasi Kerja (Y) dapat digambarkan dengan model sebagai berikut :

1. Struktur 1

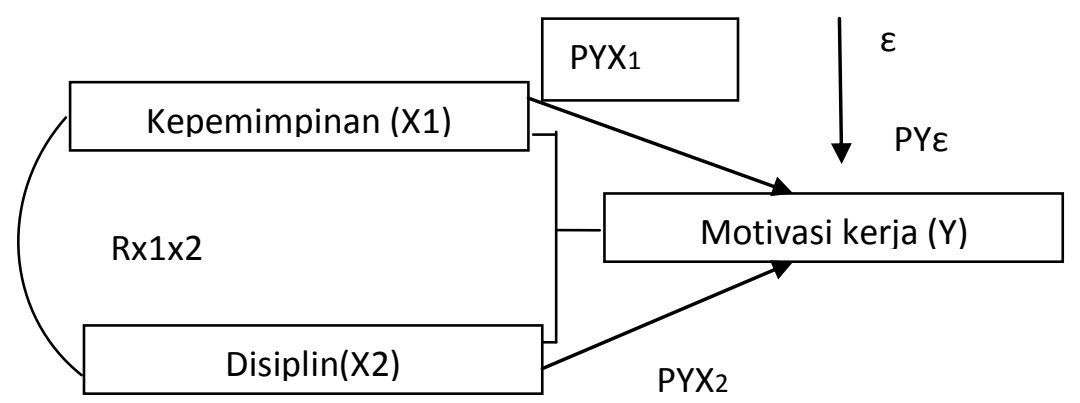

Gambar 3.1. Hubungan Struktural antara X1 dan X2 terhadap Y

Sedangkan pengaruh antar vriabel diatas dinyatakan dengan persamaan sebagai berikut :

a. Pengaruh X1 terhadap Y

- Pengaruh langsung

$\mathrm{X} 1 \rightarrow \mathrm{Y}=\mathrm{PYX} 1$. PYX1

- Pengaruh tidak langsung $\mathrm{X} 1 \Omega \mathrm{X} 1 \rightarrow \mathrm{Y}=\mathrm{PYX} 1 . \mathrm{rx} 1 \mathrm{x} 2 . \mathrm{PYX} 2$

- Pengaruh total $=$ pengaruh langsung $=$ pengaruh tidak langsung

b. Pengaruh X2 terhadap Y

- Pengaruh langsung $\mathrm{X} 2 \rightarrow \mathrm{Y}=\mathrm{PYX} 2$. PYX2

- Pengaruh tidak langsung $\mathrm{X} 1 \Omega \mathrm{X} 1 \rightarrow \mathrm{Y}=\mathrm{PYX} 2 . \mathrm{rx} 1 \mathrm{x} 2 . \mathrm{PYX} 1$ 
- Pengaruh total $=$ pengaruh langsung $=$ pengaruh tidak langsung

c. Pengaruh secara bersama-sama X1 dan X2 terhadap Y

- Pengaruh langsung = PYX1 . PYX1 + PYX2 . PYX2

- Pengaruh tidak langsung $=\mathrm{PYX} 1 . \mathrm{rx} 1 \mathrm{x} 2 . \mathrm{PYX} 2+\mathrm{PYX} 2 . \mathrm{rx} 1 \mathrm{x} 2 . \mathrm{PYX} 1$

2. Struktur 2

- Pengaruh total $=$ pengaruh langsung + pengaruh tidak langsung

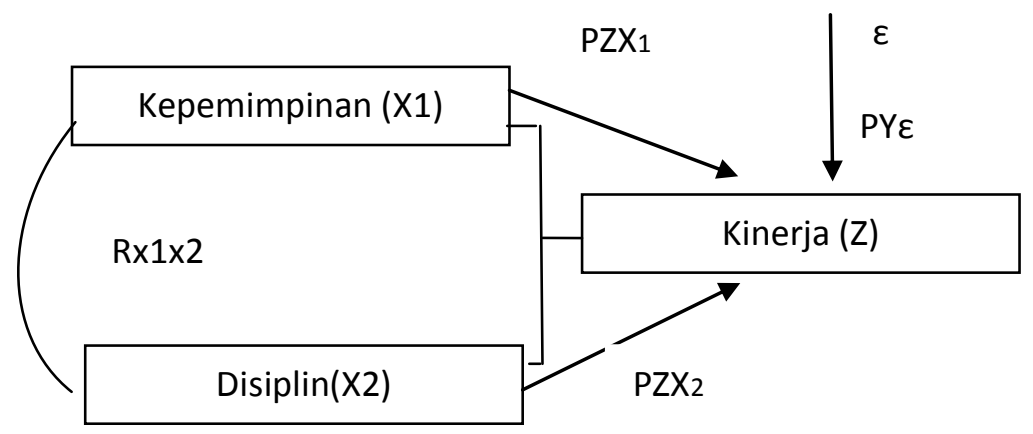

Gambar 3.1. Hubungan Struktural antara X1 dan X2 terhadap Z berikut :

Pengaruh antar variabel diatas dinyatakan dengan persamaan sebagai

$$
\mathrm{Z}=\mathrm{P} 1 \mathrm{X} 1 \mathrm{X} 1+\mathrm{PZ} \mathrm{X} 2 \mathrm{X} 2
$$

a. Pengaruh X1 terhadap Z

- Pengaruh langsung $\mathrm{X} 1 \rightarrow \mathrm{Z}=\mathrm{PZX} 1$. PZX1

- Pengaruh tidak langsung $\mathrm{X} 1 \Omega \mathrm{X} 2 \rightarrow \mathrm{Y}=\mathrm{PzX} 1 . \mathrm{rx} 1 \mathrm{x} 2 . \mathrm{PzX} 2$

- Pengaruh total $=$ pengaruh langsung $=$ pengaruh tidak langsung

b. Pengaruh X2 terhadap Y

- Pengaruh langsung $\mathrm{X} 2 \rightarrow \mathrm{Z}=\mathrm{PzX} 2 . \mathrm{PzX} 2$

- Pengaruh tidak langsung $\mathrm{X} 2 \Omega \mathrm{X} 1 \rightarrow \mathrm{Y}=\mathrm{PzX} 2 . \mathrm{rx} 1 \mathrm{x} 2 . \mathrm{PzX} 1$

- Pengaruh total $=$ pengaruh langsung $=$ pengaruh tidak langsung

c. Pengaruh secara bersama-sama X1 dan X2 terhadap Z

- Pengaruh langsung $=\mathrm{PzX} 1 . \mathrm{PzX} 1+\mathrm{PzX} 2 . \mathrm{PzX} 2$

- Pengaruh tidak langsung $=\mathrm{PZX} 1 . \mathrm{rx} 1 \mathrm{x} 2 . \mathrm{PZX} 2+\mathrm{PZX} 2 . \mathrm{rx} 1 \mathrm{x} 2 . \mathrm{PZX} 1$

- Pengaruh total $=$ pengaruh langsung + pengaruh tidak langsung Berikut adalah gambaran hubungan structural antara variabel Motivasi

Kerja (Y) terhadap variabel Kinerja (Z) :

3. Struktur 3
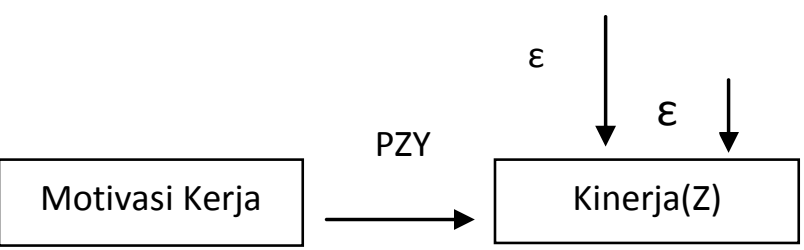

Gambar 3.3 Hubungan structural antara Y terhadap Z 
Persamaan structural untuk digram jalur diatas dinyatakan dengan

$$
\mathrm{Z}=\mathrm{PYZZ}+
$$

Pengaruh langsung variabel dinyatakan dengan

$$
\mathrm{Y} \longrightarrow \mathrm{Z}=\mathrm{PYZZ} \text {. PYZZ }
$$

Sedangkan hubungan structural antara variabel kepemimpinan dan disiplin melalui motivasi kerja terhadap kinerja dapat dijelaskan pada bagan sebagai berikut :

4. Struktur 4

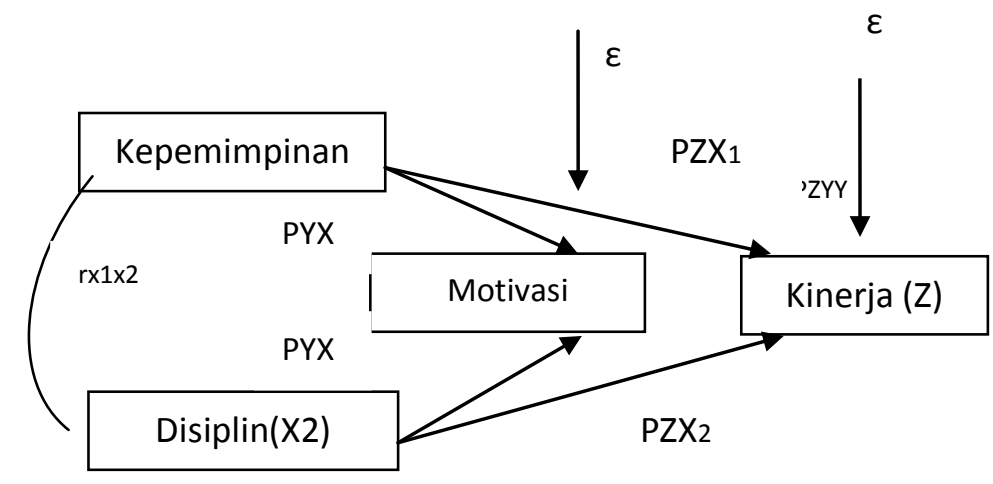

Gambar 3.1. Hubungan Struktural antara X1,X2 dan Yterhadap Z

Untuk persamaan hubungan structural diagram jalur diatas dinyatakan dengan persamaan sebagai berikut :

a. Pengaruh X1 ke Z melalui Y

- Pengaruh langsung

$\mathrm{X} 1 \rightarrow \mathrm{Z} \Omega \mathrm{Y}=\mathrm{PZx} 1$. PYx1. PZY

- Pengaruh tidak langsung

$\mathrm{X} 1 \rightarrow \mathrm{Z} \Omega \mathrm{X} 2 \Omega \mathrm{Y}=\mathrm{PZX} 1 . \mathrm{rx} 1 \mathrm{x} 2 . \mathrm{PYX} 2 . \mathrm{PZY}$

b. Pengaruh $\mathrm{X} 2 \mathrm{ke} \mathrm{Z}$ melalui $\mathrm{Y}$

- Pengaruh langsung $\mathrm{X} 2 \rightarrow \mathrm{Z} \Omega \mathrm{Y}=\mathrm{PZx} 2$. PYx2. PZY

- Pengaruh tidak langsung $\mathrm{X} 2 \longrightarrow \mathrm{Z} \Omega \mathrm{X} 1 \Omega \mathrm{Y}=\mathrm{PZX} 2 . \mathrm{rx} 1 \mathrm{x} 2$. PYX1. PZY

\section{Uji Simultan (Uji F)}

Uji simultan (uji F) digunakan untuk melihat pengaruh secara simultan antara variabel independent dengan variabel dependent. Uji F dapat dilakukan dengan cara membandingkan antara Fhitung dengan Ftabel.

Untuk uji F, criteria yang dipakai adalah :

- Jika Fhitung > Ftabel, terima Hi, tolak Ho

- Jika Fhitung < Ftabel, terima Ho, tolak Hi $\mathrm{PYX} 1=\mathrm{PYX} 2=0$

- Ho : PYX1 = 0 = tidak ada pengaruh antara variabel independent secara bersama-sama terhadap variabel dependent.

$\mathrm{PYX} 1=\mathrm{PYX} 2 \neq 0$

- Hi : PYX1 $\neq 0$ = ada pengaruh antara variabel independent secara bersamasama terhadap variabel dependent.

\section{Uji Parsial (Uji t)}

Uji t digunakan untuk melihat pengaruh secara parsial antara variabel independent dan variabel dependent. 
Berdasarkan hasil pengujian uji t, maka akan diperoleh suatu hasil berupa thitung yang akan dibandingkan dengan ttabel.

- Nilai probabilitas $<5 \%$ berarti Ho $\longrightarrow$ ditolak dan $\mathrm{Hi} \longrightarrow$ diterima, artinya koefisien jalur signifikan.

- Nilai probabilitas $>5 \%$ berarti Ho $\longrightarrow$ diterima dan $\mathrm{Hi} \longrightarrow$ ditolak , artinya koefisien jalur tidak signifikan.

\section{HASIL DAN PEMBAHASAN}

Adapun gambaran dan hasil penelitian variabel kepemimpinan, disiplin, motivasi kerja dan kinerja pegawai yang dilakukan di Rumah Sakit Bersaudara Kabupaten Bungo dengan menggunakan sampel sebanyak 54 responden. Dengan demikian dapat ditarik kesimpulan bahwa :

Kepemimpinan, disiplin, motivasi kerja dan kinerja pegawai di Rumah Sakit Umum Bersaudara baik. Berdasarkan analisa deskriftif dapat ditarik kesimpulan sebagai berikut :

1. Kepemimpinan berada pada rentang skala dengan kategori baik. Hal ini diketahui dari total skor sebesar 1.796 yang mana total skor 1.796 ini berada pada rentang skala baik $(1.468,9-1.814,4)$.

2. Disiplin berada pada rentang skala dengan kategori baik. Hal ini diketahui dari total skor sebesar 3.510 yang mana total skor 3.510 ini berada pada rentang skala baik $(2.973,7-3.628,8)$.

3. Motivasi Kerja berada pada rentang skala dengan kategori baik. Hal ini diketahui dari total skor sebesar 4.217 yang mana total skor 4.217 ini berada pada rentang skala sangat baik (3.549,7-5.940).

4. Kinerja Pegawai berada pada rentang skala dengan kategori sedang. Hal ini diketahui dari total skor sebesar 2.418 yang mana total skor 2.418 ini berada pada rentang skala baik $(1.965,6-2.570,4)$.

Kepemimpinan diduga berpengaruh signifikan terhadap motivasi kerja. Hal ini terbukti nilai t hitung $(5,520)>\mathrm{t}$ tabel $(1,68)$ maka Ho ditolak. Oleh karena itu, dapat disimpulkan bahwa kepemimpinan $\left(\mathrm{X}_{1}\right)$ secara parsial memiliki pengaruh yang signifikan terhadap motivasi kerja $(\mathrm{Y})$.

Disiplin diduga berpengaruh signifikan terhadap motivasi kerja. Hal ini terbukti nilai $\mathrm{t}$ hitung $(2,669)>\mathrm{t}$ tabel $(1,68)$ maka Ho ditolak. Oleh karena itu, dapat disimpulkan bahwa disiplin $\left(\mathrm{X}_{2}\right)$ secara parsial memiliki pengaruh yang signifikan terhadap motivasi kerja $(\mathrm{Z})$.

Kepemimpinan dan disiplin secara bersama-sama diduga berpengaruh terhadap Motivasi Kerja. Hal ini terbukti nilai f hitung $(19,673)>\mathrm{f}$ tabel $(3,18)$ maka Ho ditolak. Oleh karena itu, dapat disimpulkan bahwa hasil penggujian kepemimpinan dan disiplin secara simultan memiliki pengaruh yang signifikan terhadap motivasi kerja.

Kepemimpinan diduga berpengaruh signifikan terhadap kinerja. Hal ini terbukti nilai t hitung $(2,088)>\mathrm{t}$ tabel $(1,68)$ maka Ho ditolak. Oleh karena itu, dapat disimpulkan bahwa kepemimpinan (X1) secara parsial memiliki pengaruh yang signifikan terhadap kinerja $(Z)$.

Disiplin diduga berpengaruh terhadap kinerja. Hal ini terbukti nilai t hitung $(2,147)>\mathrm{t}$ tabel $(1,68)$ maka Ho ditolak. Oleh karena itu, dapat disimpulkan bahwa disiplin $\left(\mathrm{X}_{2}\right)$ secara parsial memiliki pengaruh yang signifikan terhadap kinerja (Z).

Kepemimpinan dan disiplin secara bersama-sama diduga berpengaruh signifikan terhadap kinerja. Hal ini terbukti nilai f hitung $(4,747)>\mathrm{f}$ tabel $(3,18)$

Pengaruh Kepemimpinan dan Disiplin terhadap Motivasi Kerja Serta Dampaknya pada Kinerja Pegawai Rumah Sakit Umum Bersaudara Kabupaten Bungo 
maka Ho ditolak. Oleh karena itu, dapat disimpulkan bahwa hasil pengujian signifikan yang berarti kepemimpinan dan disiplin secara simultan memiliki pengaruh yang signifikan terhadap kinerja.

Motivasi kerja diduga berpengaruh signifikan terhadap kinerja, Hal ini terbukti t hitung sebesar 5,966. Karena $t$ hitung $(5,966)>t$ tabel $(1,68)$ maka Ho ditolak. Oleh karena itu, dapat disimpulkan bahwa motivasi kerja (Y) secara parsial memiliki pengaruh yang signifikan terhadap kinerja $(Z)$.

\section{SIMPULAN DAN SARAN}

\section{Simpulan}

1. Kepemimpinan (X1), disiplin (X2), motivasi kerja (Y) dan kinerja pegawai (Z) di Rumah Sakit Umum Bersaudara, dimana berada pada kategori baik, Disiplin berada pada kategori baik, motivasi kerja dan kinerja pegawai berada pada kategori baik.

2. Kepemimpinan berpengaruh signifikan terhadap motivasi kerja. Oleh karena itu, dapat disimpulkan bahwa kepemimpinan $\left(\mathrm{X}_{1}\right)$ secara parsial memiliki pengaruh yang signifikan terhadap motivasi kerja (Y).

3. Disiplin berpengaruh signifikan terhadap motivasi kerja. Oleh karena itu, dapat disimpulkan bahwa disiplin $\left(\mathrm{X}_{2}\right)$ secara parsial memiliki pengaruh yang signifikan terhadap motivasi kerja (Z).

4. Kepemimpinan dan disiplin secara bersama-sama berpengaruh terhadap Motivasi Kerja. Oleh karena itu, dapat disimpulkan bahwa hasil penggujian kepemimpinan dan disiplin secara simultan memiliki pengaruh yang signifikan terhadap motivasi kerja.

5. Kepemimpinan berpengaruh signifikan terhadap kinerja. Oleh karena itu, dapat disimpulkan bahwa kepemimpinan $\left(\mathrm{X}_{1}\right)$ secara parsial memiliki pengaruh yang signifikan terhadap kinerja (Z).

6. Disiplin berpengaruh terhadap kinerja. Oleh karena itu, dapat disimpulkan bahwa disiplin $\left(\mathrm{X}_{2}\right)$ secara parsial memiliki pengaruh yang signifikan terhadap kinerja (Z).

7. Kepemimpinan dan disiplin secara bersama-sama berpengaruh signifikan terhadap kinerja. Oleh karena itu, dapat disimpulkan bahwa hasil pengujian signifikan yang berarti kepemimpinan dan disiplin secara simultan memiliki pengaruh yang signifikan terhadap kinerja.

8. Motivasi kerja berpengaruh signifikan terhadap kinerja. Oleh karena itu, dapat disimpulkan bahwa motivasi kerja (Y) secara parsial memiliki pengaruh yang signifikan terhadap kinerja (Z).

\section{Saran}

Dari hasil penelitian yang telah disimpulkan diatas, maka penulis memeberikan saran sebagai berikut ;

1. Kepemimpinan yang ada di Rumah Sakit Umum Bersaudara Kabupaten Muara Bungo dinilai baik. Meskipun sudah baik, namun tanggapan pada item ke-8 menyatakan bahwa banyak yang kerja belum sesuai dengan bidangnya. Hal ini perlu menjadi perhatian pimpinan untuk menempatkan pegawai sesuai dengan bidangnya.

2. Disiplin yang ada di Rumah Sakit Umum Bersaudara Kabupaten Muara Bungo dinilai baik. Namun masih perlu ditingkatkan lagi. Terutama mengenai balas jasa antar karyawan. Tingkat disipilin pun masih bisa ditingkatkan menjadi sangat baik. 
3. Meskipun motivasi kerja sudah baik, namun yang perlu menjadi perhatian adalah tunjangan untuk rekan kerja yang baru. Hal ini mengingat bahwa banyak responden yang memberikan tanggapan rendah pada pertanyaan tersebut.

4. Kinerja berada pada tingkat yang sedang. Ini berarti berada di bawah kategori baik. Masih perlu ditingkatkan terutama untuk mendapat penawaran kesempatan baik untuk jabatan yang lebih tinggi.

\section{DAFTAR PUSTAKA}

Bocal, Robert, 2000. Performnace Management. Alih Bahasa, Surya Dharma dan Yanuar Irawan, Gramedia Pustaka Utama, Jakarta

Burhan Bungin, 2011. Metode Penelitian Kuantitatif, Kencana Prenada Media Group, Jakarta

Danang Sunyoto (2012), Teori, Kuesioner, dan Analisis Data Sumber Daya Manusia (Praktik Penelitian), Penerbit Caps, Yogyakarta.

Gibson, James L, Ivancevich, John M, dan Donnelly, James H (2000), Organization : Behavior, Structure, Processes, Boston; Irwin McGraw-Hill.

Gomes, 2002, Management Sumberdaya manusia. Andi Offset, Yogyakarta

Hapzi Ali, Nandan Limakrisna 2013, Metodologi Penelitian Petunjuk Praktis untuk Pemecahan Masalah Bisnis, Penyusunan Skripsi, Tesis dan Disertasi, Penerbit Deepublish, Yogyakarta.

Hasibuan, Malayu, SP 2001. "Manajemen Sumber Daya Manusia” , Jakarta : Bumi Aksara

Jumadi, sheelyana, Tjiptono, Fandy, 2002. Pengaruh Prilaku Pimpinan Terhadap Inspirasi, Kekegauman dan Pemberdayaan Bawahan : Suatu Model Kepemimpinan Transformasional. Proceeding, Simposium Nasional Riset Ekonomi Dan Manajemen

Mangkunegara Anwar. P (2001). Prilaku dan Budaya Organisasi. Cetakan pertama, Retika Aditama, Bandung.

Manulang, M. 2004. Manajemen Personalia. Cetakan kedua, penerbit Gajah Mada University Press $<$ Yogyakarta.

Marwansyah dan Mukarim, 2000. Manajemen Sumberdaya Manusia. Pusat Penerbit Administrasi Niaga Politeknik Negeri Bandung. Indonesia.

Mas'ud Fuad, 2004. Survey Diagnosis Organisasional; Konsep dan Aplikasi. Badan Penerbit Universitas Diponegoro, Semarang.

Mc Cloy, John P Campbel and Robert Cudek, 1994. " A Confirmatory Test of a Model Of Performance Determinants". Journal Of Applied Psycology, Vol 78 No 4, pp. $493-505$.

Milkovich, George $\mathrm{T}$ and Boundreau John (1991), Human Resources Management. $6^{\text {th }}$ edition. Richard D. Irwin, U.S.A

Nitisemito, 2000. Manajemen Personalia. Jakarta : Ghalia Indonesia.

Robbins Stephan, 2002, Organizational Behavior, Concept, Controversies, Application, Seventh Edition, Prentice Hall, Inc. A. Simon \& Chuster Company, New Jersey

Robbins, Stephen P dan Timothy A. Judge (2008). Prilaku Organisasi. (terjemahan oleh Diana Angelica). Salemba Empat Jakarta

Riduwan 2012, Skala Pengukuran Variabel-Variabel Penelitian, Penerbit Alfabeta, Bandung

Saydam, Gozali. 2005. Manajemen Sumber Daya Manusia Suatu Pendekatan Mikro. Cetakan III. Jakarta : Djambatan 
Syekh, Sayid. 2011. “Pengantar Statistik Ekonomi Dan Sosial “. Penerbit Gaung Persada (GP), Jakarta

Soedarmayanti, 2001. Restrukturisasi Dan Pemberdayaan Organisasi Untuk Menghadapi Dinamika Perubagan Lingungan. Penerbit PT Mandar Maju, Jakarta.

Simanjuntak, J Payaman. 2000. Pengantar Ekonomi Sumber Daya Manusia. Jakarta : Fakultas Ekonomi UI.

Sinungan, Muchdarsyah. 2002. Produktivitas : Apa dan Bagaimana ? Cetakan III. Edisi Kedua. Jakarta : Bumi Aksara. 